\title{
Some thought on Shiller's narrative economics
}

\author{
Ho Manh Tung \\ Ritsumeikan Asia Pacific University
}

Oita, Japan

September 4, 2020

The Nobel Prize-winning economist Robert Shiller published an article in the American Economic Review in $2017^{1}$ and a book in $2019^{2}$, both carrying the term "narrative economics."

In these works, he criticizes the mainstream economics for neglecting the power of contagious narratives to drive major economic events (depression, recession, secular stagnation, etc.). He proposes narrative economics should be a new discipline of economics. This discipline will focus on "the spread and dynamics of popular narratives" that influence economic fluctuations.

He argues economists should seriously take on board a quantitative study of the changes in popular economic narratives. With the advent of big data and computational methods, Shiller argues there should be a greater effort in collecting time-series data on those identifiable narratives.

Indeed, it is an exciting research area full of potential for researchers who are fluent in computation and data techniques. It seems to me there are a few very hard problems for future narrative economists to overcome.

First, what should constitute "hard data" for the statistical analyses of narratives? 
Second, as Shiller points out, how do researchers differentiate between narratives that merely associate with certain economic events and narratives that cause them to happen?

Third, it is the issue of virality of narratives, for which Shiller suggests future narrative economists can draw from the well-established literature of epidemiology, i.e., the mathematics of how the virus spread through a population.

The fourth issue is the problem of meaning. Narratives can change meaning over time, which means certain narratives can acquire new meanings and gain new virality.

These broad issues are also discussed in the book and the article. I want to raise only a few points.

- First, I think narrative economics can draw from not only epidemiology but also computational folkloristics ${ }^{3,4}$, where researchers have found computational methods and data defining methods to study how folk stories evolve over time.

- Second, on the issue of meaning, I believe future narrative economists must account for the effects of culture, as so many studies have demonstrated the subtle yet systematic effects of culture on human behaviors ${ }^{5}$, it follows that cultural factors must be taken into account when analyzing how economic narratives acquire meaning.

- Third, it is not clear to me what should count as "virality."

Recently, with the arrivals of social media platforms, the new field of digital sociology and digital journalism has started to produce new methods to study why certain news stories become viral ${ }^{6}$.

I believe narrative economists can learn from these new fields. Another important component of virality is an emotion; thus, it follows that the studies of virality of economic narratives can draw from the studies of emotional contagion in the digital spaces $^{7}$. Last but not least, Shiller should have known better than many people that financial (especially, speculative) assets exhibit "fat tail distributions" and that today's risk model will need to entail jump processes ${ }^{9,10}$, which could produce "black swans"11. 


\section{References}

1. Shiller, R. J. (2017). Narrative economics. American Economic Review, 107(4), 9671004.

2. Shiller, R. J. (2019). Narrative economics: How stories go viral and drive major economic events. Princeton University Press.

3. Vuong, Q. H., Ho, M. T., Nguyen, H. K. T., Vuong, T. T., Tran, T., Hoang, K. L., ... \& La, V. P. (2020). On how religions could accidentally incite lies and violence: Folktales as a cultural transmitter. Palgrave Communications, 6(1), 82.

4. Vuong, Q. H., Bui, Q. K., La, V. P., Vuong, T. T., Nguyen, V. H. T., Ho, M. T., ... \& Ho, M. T. (2018). Cultural additivity: Behavioural insights from the interaction of Confucianism, Buddhism, and Taoism in folktales. Palgrave Communications, 4(1), 143.

5. de Oliveira, S., \& Nisbett, R. E. (2017). Culture changes how we think about thinking: From "Human Inference" to "Geography of Thought". Perspectives on Psychological Science, 12(5), 782-790.

6. Venturini, T., \& Rogers, R. (2019). “API-based Research” or how can digital sociology and journalism studies learn from the Facebook and Cambridge Analytica data breach. Digital Journalism, 7(4), 532-540.

7. Goldenberg, A., \& Gross, J. J. (2020). Digital emotion contagion. Trends in Cognitive Sciences. 24(4), 316-328.

8. Thao, H.T.P, \& Hoang, V.Q. (2015). A Merton model of credit risk with jumps. Journal of Statistics Applications \& Probability Letters, 2(2), 97-103.

9. Huu, N. V., Hoang, V. Q., \& Ngoc, T. M. (2005). Central limit theorem for functional of jump Markov processes. Vietnam Journal of Mathematics, 33(4), 443-461. 
10. Taylor, J. B., \& Williams, J. C. (2009). A black swan in the money market. American Economic Journal: Macroeconomics, 1(1), 58-83.

11. Taleb, N. N. (2007). The Black Swan: The Impact of the Highly Improbable. Random House, New York. 